\title{
РАКУРСИ УКРАЇНСЬКОЇ ТЕМИ У ТВОРЧОСТІ В. ХЛЕБНИКОВА, Б. ПАСТЕРНАКА
}

\begin{abstract}
У статті висвітлено особливості рецеепиї Украӥни у творчості письменників-авангардистів В. Хлєбникова та Б. Пастернака в аспекті імагологічної проблематики. Обидва автори пов'язані з Україною особистою та творчою біографією. Тексти Хлєбникова містять привабливі літературні етнообрази, які включають дискурс історії України, картини життя запорізьких козаків, міфологічний, фольклорний $і$ літературний контексти, замальовки пейзажів. Хлєбников активно використовує украӥнську лексику у процесі словотворення та формування образів-неологізмів. Для нього характерне зацікавлення традиціями, звичаями, побутом народу. В окремих випадках у поглядах письменника на історію Украӥни можна простежити позицію Іншого, вплив стереотипів мислення мешкания Російської імперії на сприйняття фактів національно-визвольного руху. 3 іншого боку, історична ретроспектива набуває рис ідеалізації. Загалом український дискурс відіграє значну роль у мультикультурній картині світу Хлєбникова.

Б. Пастернак зосереджується на зображенні украӥнських географічних локаиій, ландшафтних характеристиках. Художня рецепиія Украӥни є частиною загального культурного простору в його поезії. Письменник не торкається лінії нащіональної історії України, начіонально-визвольного руху ї̈ народу. Зображені ним історичні сюжети пов'язані з історією Російської імперії та відбуваються на украӥнських територіях, щчо входили тоді до ї̈ складу. Київський текст у ліриці Пастернака асоиіюється з автобіографічною лінією його літературної творчості.

Для обох письменників украӥнська тема розкривається й через зображення середовища творчої інтелігенції (опис садиби сестер Синякових і творчості художниці М. Синякової-Уречиної, зустрічей із філософом В. Асмусом, піаністом Г. Нейгаузом). Обидва письменники створюють привабливі іміджі України у своїх творах.
\end{abstract}

Ключові слова: літературні етнообрази, імагологія, міф, історичний сюжет, ландшафт.

\section{Irina ZAYARNA, orcid.org/0000-0003-1926-1860 Doctor of Philological Sciences, Professor at the Department of Russian Philology Taras Shevchenko National University of Kyiv (Kyiv, Ukraine)i.zayarna@ukr.net}

\section{ASPECTS OF THE UKRAINIAN THEME IN THE LITERARY WORKS BY V. KHLEBNIKOV, B. PASTERNAK}

The article highlights the peculiarities of the reception of Ukraine in the creative works of the avant-garde writers Khlebnikov and Pasternak in the aspect of imagological problems. Both poets are linked with Ukraine by personal and creative biographies. Khlebnikov's texts contain attractive literary ethno-images, including the discourse of Ukrainian history, pictures of the life of the Zaporozhian Cossacks, mythological, folklore and literary contexts, sketches of landscapes. Khlebnikov actively uses Ukrainian vocabulary in the process of word-creation and making of images-neologisms. He shows an interest in traditions, customs, everyday life of the people. In some cases in the writer's attitude we can trace the position of the Other, that is influenced by the stereotypes of thinking of a citizen of Russian Empire towards the certain facts of the Ukrainian national liberation movement. Generally, Ukrainian discourse plays a significant role in his multicultural worldview.

Pasternakfocuses on the depiction of Ukrainian geographic locations, landscape characteristics. The artistic reception of Ukraine is a part of his joint cultural space in his poetry. The writer does not touch upon the line of the national history of Ukraine, the national liberation movement of its people. The historical subjects depicted by him are connected with the history of the Russian Empire and take place in the Ukrainian territories which were then the part of it. The Kiev text in the Pasternak's lyrics is associated with the autobiographical line of his literary work.

For both writers, the Ukrainian theme is revealed through the image of the creative intelligentsia (description of the estate of the Sinyakov sisters and the work of the artist M. Sinyakova-Urechyna, meetings with the philosopher V. Asmus, pianist $G$. Neuhaus). Both writers create attractive images of Ukraine in their works.

Key words: literary ethnoimages, imagology, myth, historical plot, landscape. 
Постановка проблеми. В. Хлєбников і Б. Пастернак - видатні письменники, яскраві величини у мистецькому просторі XX ст. Їхня творчість виявляє зовсім різні картини світу й ідіостилі, але письменників об'єднує належність до футуристичного руху й активне застосування принципів авангардної поетики на початку творчих шляхів. Обох авторів пов'язують з Україною факти особистої та письменницької біографії - подорожі, родинні зв'язки, спілкування із представниками української творчої інтелігенції. Варто згадати і звернення до історичного минулого України, до iï мови, міфології, опертя на літературні традиції та контексти. Відповідно, можна простежити широкий спектр рецепції та віддзеркалення українських реалій у їхніх текстах.

Аналіз досліджень. Про українські джерела російського авангарду неодноразово йшлося в літературознавстві, зокрема у працях Д. Горбачова (Горбачов, 2008; 2014), В. Кравця (Кравець, 1993; 1998), М. Петровського (Петровский, 1990), Р. Мовчан (Мовчан 2010) та ін. літературознавців і культурологів. Тим більше, що колискою найбільш радикального крила - кубофутуризму - стала Херсонсонщина, село Чернянка, де в будинку братів Бурлюків сформувалося мистецьке об'єднання «Гілея». Ця місцина була опоетизована у художніх творах і в мемуарах учасників групи - Б. Лівшиця (Лившиц, 1989), В. Каменського (Каменский, 1990), згадувалася у книзі В. Маркова (Markov, 1968). Зв'язки Хлєбникова з Україною розглядалися переважно в аспекті біографічному - 3 огляду його походження з боку матері, адже письменник вважав себе нащадком запорожців: «В моих жилах есть армянская кровь (Алабовы) и кровь запорожиев (Вербиикие), особая порода которых сказалась в том, что Пржевальский, Миклуха-Маклай и другие искатели земель были потомками птенизов Сечи» (Хлебников, 1986: 641). Предметом розгляду були його безпосередні зв'язки з Україною - мандрівки, перебування в Харкові, Києві, на Херсонщині, Волині, в Карпатах, спілкування 3 українськими митцями. Наприклад, докладний опис «святошинських вакацій» Хлєбникова міститься в розвідці Мирона Петровського (Петровский, 1990). У різні часи дослідники вказували на українські фольклорні й міфологічні джерела творчості В. Хлєбникова, на значний український лексичний шар його творів і на те, що саме українізми формують у багатьох випадках основу його поетичних неологізмів (Степанов, 1975; Кравец, 1998; Баран, 2002; Вроон, 2000). В. Кравець акцентує увагу на зв'язках творчості Хлєбникова iз традиціями Г. Сковороди, М. Гоголя, Т. Шевченка: «В отношении украинской литературной традиции от Котляревского, Кулиша, Костомарова до Коцюбинского и Леси Украинки включительно» (Кравец, 1998: 13).

На більш глибинні літературні витоки ігрової поетики, зокрема на проекцію барокового дискурсу, вказували Р. Якобсон (Якобсон, 1921), порівнюючи паліндроми письменника 3 паліндромними віршами Івана Величковського, а також Д. Чижевський. У низці праць відомий український дослідник окреслює паралелі творчості Хлєбникова 3 бароковою поезією українських митців (Чижевський, 1963; 2003).

Щодо українських контекстів у творчості Б. Пастернака, то тут у дослідницькій літературі радше йшлося про біографічні події, пов'язані 3 перебуванням поета в Україні, про його творчі зв'язки з українськими митцями та про перекладацьку діяльність. На жаль, досі в літературознавстві бракує цілісного висвітлення особливостей українського дискурсу у творчості письменниківавангардистів як із погляду імагології, так і в безпосередній площині поетики окремих творів.

Мета статті - висвітлити особливості втілення української теми у творчості Хлєбникова і Пастернака 3 позицій імагологічних критеріїв, визначити специфіку літературних етнообразів і їхню роль у художньому світі письменників. У сучасних гуманітарних науках через підвищений інтерес до проблем національної ідентичності ці завдання набувають особливої актуальності.

Виклад основного матеріалу. В. Хлєбников цілковито належав до мандрівного типу філософів і лишив чимало поетичних споминів про різні куточки України. Попри те, що тоді українські території входили до складу Російської імперії, Хлєбникову вдалося достеменно передати національну специфіку, місцевий колорит і створити привабливі літературні етнообрази. Як зазначає В. Будний, у поняття літературного етнообразу можуть включатися етнічна (національна) ідентичність зображуваних персонажів, ландшафти та історичне минуле народу (Будний, 2007). Саме ці складники формують образ України у Хлєбникова. Цікаво простежити, як у творах письменника відобразилися українські географічні локуси. Наприклад, у поезії «Крымское» відтворено чудові імпресіоністичні замальовки морських пейзажів, виконані в яскравій золотистосиній колористичній тональності. Письменник використовує образну синестезію, передає рух вітру, запахи маслини, брижі на воді. Він вдається 
тут і до словесної омонімічної гри: «Море в этом заливе совсем засыпает. / Засыпают / Рыбаки в море невод. / Небо там золото: / Посмотрите, как оно молодо!» (Хлебников, 2000).

Водночас, у тексті вміщено й побутові сценки біля моря, наприклад, зображено улюблене заняття дітей - кидання камінців у воду. Письменник влучно вмонтовує фрагменти української мови, якою спілкуються місцеві рибалки: «Рыбаки не умеют. / Наклонясь, сети сеют. / Рабочий спрашивает: "А чи я бачил?» (Хлебников, 1986: 45). Із пунктирних замальовок-фрагментів складається багатошаровий текст, головний меседж якого - передати настрій ліричного героя, сповненого вражень від яскравого літнього дня на березі моря. У вірші чітко окреслюється романтична особистість ліричного героя.

У такому ж ключі написано i «Кримський цикл», що складається 3 десяти поетичних мініатюр. Тут з'являється конкретна локалізація, вказано містечко Судак, якому присвячено окрему поетичну мініатюру. Хлєбников вдається до притаманної авангардистам техніки примітивізму, створюючи таку картинку: «Кузнечик / Вечер / Ткет. Качались рыбалки... / И женские голоса / Тишины балки. / Ясна неба полоса» (Хлебников, 2000).

До ранніх творів, у яких відлунюють враження письменника, навіяні південними краєвидами, належить і прозовий уривок, присвячений двоюрідному братові Миколі Рябчевському, талановитому скрипалю. Тут яскраво передано одеський колорит і побут. Автор змальовує діяльність рибалок, їхні оселі біля моря, розваги дорослих і дітей, котрі приїхали відпочивати на морське узбережжя: «B Одессе, а это было в Одессе, многие переселялись на берег моря в легкомысленных клетушках, воздвигая их вдоль тропинок, угощяая в праздники толпу дорогим чаем и дешевыми песенками.

В этой полурыбачкой жизни находили прелесть» (Хлебников, 1986: 515).

Інший локус, який постійно наявний у художніх творах Хлєбникова, пов'язаний із Харківщиною та перебуванням у місцині Червона Поляна. Тут на хуторі, у великому будинку жили талановиті сестри Синякови, які стали музами для багатьох поетів-авангардистів. До їхньої гостинної оселі навідувалися Б. Пастернак, В. Маяковський, М. Асєєв, Г. Пєтніков. Часто зупинявся тут і Хлєбников. Найбільш відома серед сестер - Марія Синякова-Уречина, художниця-авангардистка, чиї картини, акварелі, малюнки гуашшю й олівцем підкорили світ. Сестрам Синяковим поет присвятив низку текстів, зокрема поему «Синие оковы». Детальний аналіз поеми, визначення ii1 саме як ліричної здійснено у статті Л. Спесивцевої. Авторка підкреслює, що це «поема станів, дія якої рухається потоком свідомості ліричного героя» (Спесивцева, 2005). Саме такий структурний принцип об'єднує різноманітні теми й мотиви твору, які віддзеркалюють соціально-історичну, філософську, автобіографічну, міфопоетичну лінії.

Втім, крізь складний багатошаровий метафоричний текст, у якому, як завжди у Хлєбникова, зашифровано багато смислів, проступають окремі обриси, деталі українського сільського світу, побуту й природи, що супроводжуються місцевою говіркою: «Вечер. За садом, за улицей, говор на «ча»: / «Чи чадо сюда прилетело? / Мало дитя?» / Пчель телегу сплели! / Ласточки пели «цивить!» (Хлебников, 1986: 363).

У поемі можна простежити відгомін творчої атмосфери, яка панувала в садибі Червоної Поляни, завдяки заняттям малярством Марії. На це вказують промовисті деталі: «Синими крыльями красный закутан был угол», «на радуге веселья взора» i т. ін. Своєрідною проекцію живопису може вважатися й насичена колористична палітра твору. Текст містить елементи екфразису - картини Марії Синякової-Уречиної, зокрема їі відомого малюнку «Війна» (1915), на якому зображено вибух бомби, вторгнення у мирне життя караючого меча війни: «коса войны, чумы, меча ли / Косила колос сел» (Хлебников, 1986: 376).

Червона Поляна згадується також у поеміутопії «Ладомир», написаній пізніше. Садиба Синякових, життя й побут сестер опоетизовано також в оповіданні «Малиновая шашка». Цей текст цікавий і з погляду віддзеркалення у ньому історичних подій - боротьби за владу в Україні в 1919 р., зміни урядів і, зрештою, її більшовицького захоплення. Саме так кваліфікує письменник ці зміни, хоча й вдається до метафоричної мови: «Теперь было время советской волны. $<\ldots>$ Дул ветер Москвы. Суровый всадник голодающего севера, казалось, с какой-то неохотой вступал в завоеванный край, точно в самом начале встретил женщину с ведрами или заяи с странной храбростью перебежал дорогу. Парус Оки высоко стоял над Украиной, и надпись «я страшен» зияла на нем» (Хлебников, 1986: 557). Як мешканець тодішньої Російської імперії Хлєбников часом демонструє погляд Іншого (Чужого) у ставленні до проблем української національновизвольної боротьби та народної революції. Це відчувається у його скептичному зауваженні 3 приводу хвилі українізації. Позиція Хлєбникова, котрий безумовно відчуває свою спорідненість 3 Україною, багато в чому відрізняється від позиції 
М. Булгакова, який у романі «Біла гвардія» негативно, з погляду офіцера-білогвардійця, оцінив боротьбу українського народу за незалежність від багаторічного московського ярма.

В оповіданні «Малиновая шашка» цікаво перетинаються реальне й вигадане. Центральний персонаж - Петро - хвалиться своїми героїннии бойовими вчинками, але, як з'ясовується згодом, не має до них жодного стосунку і навіть плями крові на своїй зброї вимальовує фарбами. Хлєбников відтворює дійсність окремими штрихами, фрагментами, які складаються в цілком імпресіоністичну картину. Він змальовує затишний побут садиби Синякових, портретує зовнішність сестер, підкреслює красу природи Червоної Поляни: «вы вдруг бежали из города в глухую усадьбу, в зеленый плодовый сад, где ивели вишни и яблони, ворковали голубки и мяукали иволги» (Хлебников, 1986: 558). Письменник використовує поетику контрасту і вибудовує метафоричну образну модель, показує, як навіть у цей тихий і зачарований світ вривається війна: «Конь гражданской войны, наклоняя желтые зубы, рвал и ел траву людей» (Хлебников, 1986: 557).

Але попри важкі часи, художниця продовжує свою роботу. Сліди фарб, полотна, дивні предмети у маєтку, наприклад, глиняний череп, котрий одночасно схожий на метелика та глечик, свідчать про творчість живописця. Елементи живопису, безумовно, присутні у словесних портретах, які письменник дає сестрам Синяковим: «Если тайна живописи возможна на холсте, досках, извести и других мертвых вещах, - она возможна, разумеется, и на живых лицах» (Хлебников, 1986: 561).

Українська тематика й образність, географічні локуси, топоніми, що представляють Україну, пов'язані з міфопоетичним та історичним пластами творчості Хлєбникова. Зокрема, відомі тексти «Мавка», «Ночь в Галиции», «Мава Галицийская» відображають фольклорну стихію Карпатських країв, про що йшлося в дослідженнях вчених (Кравец, 1993; Баран, 2002; Седакова, 2000: 352-356).

Давньослов'янські міфологічні вірування письменник асоціює насамперед з історією Київської Русі. Наприклад, у поезії «Перуну» згадуються події хрещення Русі князем Володимиром і шлях по Дніпру дерев'яного язичницького божества. Найдавніші часи Києва та Чернігова Хлєбников вписує в контекст вічності у творі «Через строй столетий». У його текстах можна знайти відомості про наукові відкриття й археологічні знахідки. Зокрема, він згадує про «коней с Чартомлькского блюда» у тексті «Табун шагов, чугун слонов!...». Тут ідеться про артефакт скіфської історії - віднайдену амфору із зображенням коней зі скіфського кургану, розташованого поблизу міста Нікополя.

Важлива тема для Хлєбникова, який вважав себе нащадком запорізьких козаків, - історія Запорізької Січі, козацька вольниця, визвольний рух гайдамаків. У літературознавстві існує думка, що свій вірш «Заклятие смехом» Хлєбников написав під враженням від картини I. Рєпіна «Запорожці пишуть листа турецькому султану» $\mathrm{i}$, подібно до художника, але за допомогою словесних форм, показав різні типи сміху.

Як і для Гоголя, Запорізька Січ овіяна для Хлєбникова романтикою. Він неодноразово згадує легендарних особистостей - київських князів, запорізьких отаманів, гетьманів, представників козацької старшини, народних героїв - Остраницю, Олелька, Байду, Сірка, Морозенка та ін.

Окремий сюжет із життя козаків представлений у невеликій замальовці «Смерть Паливоды», що становить одну із частин його твору «Дети Выдры». Тут наявна героїзація, підкреслення могутності та військової звитяги запорожців: «казалось, казачкий меч сорвался с чьих-то плеч и плясал гопака по всей стране» (Хлебников 1986: 438). В уривку постають подробиці похідного побуту, опис зброї, побутових предметів, які повсякчас супроводжували козаків у походах. Автор включає рядки народної пісні, милується рисами зовнішнього вигляду запорожців - традиційними чубами-«оселедцями». Усе це свідчить про знання письменником історичних реалій Запорізької Січі. Хлєбников поетизує природу безкрайого українського степу, невід'ємною часткою якого є пісня жайворонка. Нескінченно милується він також «пылающим от багрянца морем».

У творах можна простежити традиційний ідилічний дискурс зображення України, що постає в образах-константах: «Увидел синий дымм, $и$ белую хату, и подсолнух, и вишни» (Хлебников 1986: 438). Про моделі ретро-утопії у Хлєбникова, образи України як Рая Земного та проекцію в них творчості Шевченка, зокрема його відомої поезії «Садок вишневий коло хати...», йшлося в дослідженні В. Кравця (1998: 13). Безперечна тенденція до використання усталених національних образів сільської місцевості неодноразово зустрічається у Хлєбникова і в інших текстах. Наприклад, у його поемі «Полужелезная изба» неодмінними деталями стають: «вишневый хутор, холмы у млына, в полях головки белокурые, у сельской хаты те же белье цветыл» (Хлебников, 2002). 
У всіх описах простежується щире зацікавлення автора українською історією, захоплення традиціями та звичаями народу. Водночас письменник частково перебуває в полоні стереотипів і помилкових уявлень про історію українського козацтва як частини історії Російської імперії. Тому в «Смерті Паливоди» неодноразово можна зустріти сприйняття звичаїв Запорізької Січі як «російської відповіді» західним лицарям, а успішні бойові дії запорожців, які розбили полчища ворога, охарактеризовані як «перемога росіян». Тут ми знову бачимо чітку ілюстрацію «погляду Іншого», оцінку подій із позицій «Чужого». Подібне «приписування» Росії української історії, особливо її давніх часів (ототожнення 3 Руссю), було нормою протягом усього періоду існування Російської імперії, починаючи з петровських часів, воно міцно укорінилося в ментальних стереотипах аж до періоду іiі занепаду, хоча пізніше з успіхом перекочувало в радянську імперію.

Вплив стереотипів колоніального мислення й імперської культури дається взнаки і в ранньому оповіданні Хлєбникова «Велик-день (подражание Гоголю)», де окреслюється малоросійський дискурс. Герой оповідання потрапляє до одного 3 мальовничих українських куточків, милується його природою, описує звичаї та національне вбрання його мешканців (кирею, хустку, вінок, намисто), активно вводить українську мову. Водночас він вважає, що потрапив в «уголок исконной России», а його жителів, плутаючи, називає то малоросіянами, то росіянами, не простежує національної ідентичності українців.

Що стосується теми гайдамаків, яка звучить у поетичному творі «Из песен гайдамаков», то тут Хлєбников радше акцентує на розбійницькому молодецтві, анархізмі учасників руху, не розкриває національно-визвольної природи цього історичного явища.

Загалом же українська тема органічна для Хлєбникова, а літературний етнообраз України постає невід'ємною частиною його художньої свідомості. Українська тематика частково розкривається через міфопоетичний простір, фольклорну лінію й історичні контексти у його творчості.

Для Хлєбникова надзвичайно важливий і пласт української лексики, яка $є$ важливим складником його поетичної мови та його творчих експериментів зі словом у процесі формування авторських образів-неологізмів. Через етимологію письменник проникає у приховані смисли та природу слова.

На відміну від Хлєбникова. українська тематика у творчості Б. Пастернака обмежується переважно зображенням географічних локусів і враженнями від мандрівок і відвідування різних куточків України в різні періоди його життя. Через них розкривається автобіографічний пласт його творів.

Цікаво, що в його поезії також зображено хутір Червону Поляну, де він гостював у сестер Синякових. Якщо Хлєбников не дає розгорнутих замальовок садиби, а обмежується лише окремими імпресіоністичними деталями, то Пастернак у поезії «Мельницы» розгортає досить широкий краєвид сільської місцевості - «плакучий Харьковский уезд». Тут безліч зорових і акустичних образів, які складаються в об'ємну синестетичну картину. У нічному пейзажі помітні типові риси українського сільського ландшафту: нерівна місцевість, пагорби, спуск до ставка, обриси світлих будівель, перелік характерної для цієї місцевості рослинності - вишні, яблуні, настурції. Метафоричнообразно передано світлове рішення - місячне сяйво, що заливає землю: «Село в серебряном плену» (Пастернак, 1990: 108). Контури будівель і рослин виписані неясно, крізь серпанок. Поет досить докладно і водночас мовою ускладненої метафори зобразив конструкцію й роботу млина, опоетизував технічний бік життєдіяльності людей.

Зауважимо, що опис реального географічного локусу у Пастернака становить органічну частину садово-паркової парадигми в його творчості, яка визначається метафорою «життя - сад», однією 3 констант його картини світу. Як будьякий локальний пейзаж, сільський краєвид вписаний у Пастернака у простір космосу і світобудови загалом. Не випадково в окресленні млинів він вдається до образного ряду глобального масштабу: «им ветер был роздан, как звездам - свет» (Пастернак, 1990: 109).

$\mathrm{He}$ менш значущі для поета південні географічні локації. У поезії «Степь» розгорнуто мальовничу картину степу в районі Керчі: «nрuмолкла и взмокла безбрежная степь», «туман отовсюду нас морем обстиг». Місцевий колорит передано за допомогою українізмів: «На Млечный Путь стороной ведет / На Керчь, как шлях, скотом пропьлен. / Зайти за хать, и дух займет:/ Открыт, открыт с четырех сторон» (Пастернак, 1990: 141). Безмежний степ постає як частина всесвіту у властивій Пастернакові манері не підкреслювати відмінність між великим і малим, між побутовим і вселенським: «Тенистая полночь стоит у пути, / На шлях навалилась звездами, / И через дорогу за тын перейти / Нельзя, не топча мирозданья» (Пастернак 199: 142).

Південні пейзажі Одеської області, колишньої Бессарабії, виявляються частиною культурного простору в ліриці Пастернака. У його текстах ожи- 
вають історико-культурні реалії, пов'язані з південним засланням Пушкіна. Наприклад, у циклі «Теми и вариации», у варіаціях на тему пушкінської поеми «Цыгане», автор змальовує степ, морське узбережжя і шторм на морі поблизу селища Шабо, яке відвідував Пушкін: «И шквал за Шабо бушевал, / и выворачивал причальы. / В рассоле крепла бечева, / И шторма тошнота крепчала» (Пастернак, 1990: 171).

Згадуються в тексті й сусідні населені пункти молдавська фортеця Кагул і Очаків, які також у період свого перебування в Одесі відвідав Пушкін. Очевидно, що вибір топонімів визначається для Пастернака саме знаком пушкінської присутності у згаданих місцях.

Опис південних українських локусів, зокрема фортеці та міста Очаків, уводиться поетом у зв'язку із сюжетом недавньої історії. Драматичні події повстання Чорноморського флоту 1905 р. зображені в поемі «Лейтенант Шмидт». На тлі трагічної долі головного героя, офіцера російського флоту, який очолив повстання на крейсері «Очаків», але після його поразки був засуджений на смерть, картина міста виглядає похмуро і сумно. У ній виокремлюються кам'яні стіни фортеці та в'язниці, піщана коса як частина пейзажу і морські чайки. Поет намагається передати колорит і атмосферу провінційного містечка, його побут, забудову, показати його запустіння і занедбаність, нудьгу, що панує в ньому. Відсутність чіткої межі між міським і рустикальним просторами підкреслено деталями анімалістичного ряду: «распев петухов по утрам», «свиней и галок вдосталь» (Пастернак, 1990: 294).

Порівняння міста 3 пеклом - а саме таким воно обернулося для арештованих і засуджених на смерть матросів - вдало вибудовується через обігравання літературної ремінісценції - Дантового пекла: «Однако, как свежо Очаков дан у Данта! / Амбары, каланча, тачанки, облака....» (Пастернак, 1990: 294). Похмурі картини міста супроводжуються незмінними образами дощів, які у поезії Пастернака вміщують різні смислові контексти. Тут домінує семантика смутку, страждання: «Над Очаковом пронёс. Ветер тучу слёз и хмари», «Шлёпнулся и всею тучей / Водяной бурдюк дождя» (Пастернак, 1990: 296).

У таких же непривабливих тонах, на тлі розбурханої природної стихії окреслені й прилеглі географічні локуси - острів Березань та історична Ольвія, археологічна пам'ятка грецького поселення в Миколаївській області. У поетиці Пастернака культура, природна стихія та історія злиті нерозривно, і поема «Лейтенант Шмидт» - ще одне підтвердження цієї філософської концепції.
Міський текст, який представляє Київ та Ірпінь у ліриці Пастернака, проектується на автобіографічну любовну лінію, що простежується в його книзі «Второе рождение». Ці тексти створювалися пізніше, у 30-ті рр., коли Пастернак вже попрощався 3 поетикою футуризму, проте багато прийомів, зокрема ускладнений метафоризм, синестезія та інтермедіальність, випробувані в ранній період творчості, залишалися для нього актуальними. У низці текстів урбаністичні пейзажі розгорнуті на тлі образів музики. Так, у поезії «Баллада» київські топоніми «недвижныий Днепр, / ночной Подол», «парк на крутояре» супроводжуються згадкою про музику Шопена. Автобіографічною канвою тут слугує прослуханий поетом концерт Генріха Нейгауза, котрий виконував музику Шопена в Купецькому саду в Києві. В іншому разі у тексті «Опять Шопен не ищет выгод...» реалії міста - «два клена в ряд, за третьим разом - / Соседней Рейтарской квартал», «подсвечники каштанов» - знов отримують музичне обрамлення: «гремит Шопен, из окон грянув» (Пастернак, 1990: 363).

Через київський текст розкривається особиста сфера почуттів, пов'язана зі стосунками поета 3 майбутньою другою дружиною - Зінаїдою Нейгауз: «Твое присутствие, как город, / Как тихий Киев за окном, / Который в зной лучей обернут» (Пастернак, 1990: 302).

У поетичному творі «Лето» відбилися враження Пастернака періоду перебування на дачі у філософа В. Асмуса в Ірпені. У тексті чимало пейзажних деталей, образів флори та фауни, завдяки їхньому поєднанню створюється фрагментарна, імпресіоністична замальовка літньої приміської природи. Як і в ранній ліриці, Пастернак вдається до експресивного словесного живопису, застосовує неповторні метафоричні образи. Наприклад, таким химерним в уявленні поета постає захід сонця: «Загон горизонта смыкал полукруг. / Зарницы вздымали рога по-оленьи» (Пастернак, 1990: 351). Особливості місцевого ландшафту також окреслені у незвичайних словесних конструкціях: «балка у входа ютила удода», «лениво паслись облака в отдаленьи», «сумерек хитрый маневр / Сводил с полутьмою зажженный репейник» (Пастернак, 1990: 351).

У тексті наявна низка алюзій, натяків на події тогочасного культурного життя. Так, письменник згадує діалог Платона «Бенкет», який саме тоді був перевиданий у російському перекладі 3 коментарями В. Асмуса. За асоціацією автор звертається до пушкінського тексту «Бенкет під час чуми» та неочікувано поєднує в одному 
цитатному просторі жіночих персонажів із двох творів різних епох.

Висновки. Таким чином, українська тематика у творчості представників авангарду - В. ХлебниковаіБ.Пастернака-представлена багатоаспектно.

У мультикультурній картині світу Хлєбникова Україна займає особливе місце. Ї̈ї літературний етнообраз включає факти історії, згадку про відомих історичних осіб, знакових постатей національно-визвольного руху, елементи фольклору, міфології, описи географічних локусів і пейзажі, зображення побуту творчого середовища. Важливу роль відіграє активне використання української мови у власній словотворчості, а також звернення до літературних контекстів (Гоголя, Шевченка та ін.). У текстах письменника можна простежити позицію Іншого, котрий перебуває під впливом стереотипів імперського мислення щодо окремих фактів національно-визвольного руху. Водночас Хлєбников виявляє щиру цікавість до національної складової частини української історії, традицій і звичаїв народу.
Для Пастернака художня рецепція України постає насамперед частиною загального культурного простору в його творчості. Образи України окреслюються переважно через мальовничі краєвиди, поетичні зображення географічних локусів, які він відвідав, враження й переживання ліричного героя.

Водночас національний колорит простежується в описах побуту й у використанні української лексики. Письменник не торкається лінії національної історії України, національновизвольного руху ii народу. Для нього значимі історичні сюжети тодішньої Російської імперії, які, фактично, відбувалися на теренах українських земель, що входили в ті часи до складу імперії, південне заслання Пушкіна, повстання на Чорноморському флоті. Київський текст у ліриці Б. Пастернака 30-х рр. пов'язаний з автобіографічною лінією його творчості.

Загалом же можна говорити про створення позитивного і привабливого іміджу України в текстах обох поетів-авангардистів.

\section{СПИСОК ВИКОРИСТАННИХ ДЖЕРЕЛ}

1. Баран Х. О Хлебникове. Контексты, источники, мифы. Москва : Российск. гос. гуманит. ун-т., 2002. 416 с.

2. Будний В. Розгадка чарів Цірцеї: національні образи та стереотипи в освітленні літературної етноімагології. Слово і Час. 2007. № 3. URL: http://dspace.nbuv.gov.ua/bitstream/handle/123456789/11392/07-Budnyy.pdf (Дата звернення: 12.07.2020).

3. Вроон Р. О семантике гласных в поэтике Велимира Хлебникова. Поэзия и живопись: Сб. трудов памяти Н. И. Харджиева. Москва : Языки русской культуры, 2000. С. 357-368.

4. Горбачов Д. Гопашно-шароварна культура як джерело світового авангарду. Львів : Смолоскип, 2008. 96 с.

5. Горбачов Д. Чукурюк! Брати Бурлюки. Київ : Ярославів вал, 2014. С. 214-241.

6. Каменский В. Путь энтузиаста. Каменский В. Сочинения. Репринтное воспроизведение изданий 1914, 1916 , 1918 г2. Москва : Книга, 1990. 591 с.

7. Кравец В. Велимир Хлебников и украинская мифология : дис. ... канд. филол. наук / АН Украины, Ин-т лит. им. Т. Г. Шевченко. Киев, 1993.

8. Кравец В. Разговор о Хлебникове. Киев : РВЦ «Проза», 1998. 288 с.

9. Лившиц Б. Полутораглазый стрелец: Стихотворения, переводы, воспоминания. Ленинград : Советский писатель, $1989.720 \mathrm{c}$.

10. Мовчан Р. Хлєбников і український футуризм. Бахмутський шлях. 2010. № 1-2. С. 131-136.

11. Пастернак Б. Стихотворения и поэмы. Ленинград : Советский писатель, 1990. Т. 1. 504 с.

12. Петровский М. Святошинские вакации Велимира Хлебникова. Петровский М. Городу и миру. Киевские очерки. Киев : Радянський письменник, 1990. С. 93-97.

13. Седакова О. Этнографический комментарий к одной строфе Хлебникова. Поэзия и живопись: Сб. трудов памяти Н. И. Харджиева. Москва : Языки русской культуры, 2000. С. 352-356.

14. Степанов Н. Велимир Хлебников. Жизнь и творчество. Москва : Советский писатель, 1975. 281 с.

15. Спесивцева Л. Жанровое своеобразие поэмы В. Хлебникова «Синие оковы». Вестник Астраханского гос. ун-та. 2005. № 6 (29). C. 281-292. URL: https://cyberleninka.ru/article/n/zhanrovoe-svoeobrazie-poemy-v-hlebnikovasinie-okovy/viewer (Дата звернення: 12.07.2020).

16. Хлебников В. Творения. Москва : Советский писатель, 1986. 736 с.

17. Хлебников В. Полное собрание сочинений. Т.1 Стихотворения 1904-1916. Москва : ИМЛИ РАН, Наследие, 2000. URL: https://ruslit.traumlibrary.net/book/hlebnikov-ss06-01/hlebnikov-ss06-01.html (Дата звернення: 04.11.2020).

18. Хлебников В. Полное собрание сочинений. Т. 3. Поэмы 1905-1922. Москва : ИМЛИ PAH, 2002. URL: https://ruslit.traumlibrary.net/book/hlebnikov-ss06-03/hlebnikov-ss06-03.html (Дата звернення: 04.11.2020).

19. Чижевский Д.Опоэзии русского футуризма. The New Review. Новыйжурнал. Нью-Йорк, 1963.Кн. 73. С. 132-169.

20. Чижевський Д. Українське літературне бароко. Київ : Обереги, 2003. 576 с.

21. Якобсон Р. Новейшая русская поэзия. Набросок первый: Подступы к Хлебникову. Прага, 1921. URL: http:// philologos.narod.ru/classics/jakobson-nrp.htm (Дата звернення: 12.07.2020).

22. Markov V. Russian Futurism: A History. Berkeley and Los Angeles: Univ. of California Press, 1968. 467 p. 


\section{REFERENCES}

1. Baran Kh. O Khlebnikove. Konteksty, istochniki, mify. [About Khlebnikov. Contexts, sources, myths]. Moskva: Rossiysk. gos. gumanit. un-t., 2002. 416 p. [in Russian].

2. Budnyy V. Roz hadka chariv Tsirtseyi: natsional'ni obrazy ta stereotypy v osvitlenni literaturnoyi etnoimaholohiyi. [Unraveling the magic of Circe: national images and stereotypes in the light of literary ethnoimagology]. Slovo $i$ Chas. 2007. № 3. URL: http://dspace.nbuv.gov.ua/bitstream/handle/123456789/11392/07-Budnyy.pdf (Accessed: 12.07.2020) [in Ukrainian].

3. Vroon R. O semantike glasnykh v poetike Velimira Khlebnikova. [On the semantics of vowels in the poetics by Velimir Khlebnikov]. Poeziya i zhivopis': Sb. trudov pamyati N. I. Khardzhiyeva. Moskva: Yazyki russkoy kul'tury, 2000. P. 357368. [in Russian].

4. Horbachov D. Hopashno-sharovarna kul'tura yak dzherelo svitovoho avanhardu. [Hopashno-sharovana culture as a source of world avant-garde]. L'viv: Smoloskyp, 2008. 96 p. [in Ukrainian].

5. Horbachov D. Chukuryuk! [Chukuryuk!]. Braty Burlyuky. Kyyiv: Yaroslaviv val, 2014. P. 214-241. [in Ukrainian].

6. Kamenskiy V. Put' entuziasta. [The Enthusiast's Way]. Kamenskiy V. Sochineniya. Reprintnoye vosproizvedeniye izdaniy 1914, 1916, 1918 gg. Moskva: Kniga, 1990. 591 p. [in Russian].

7. Kravets V. Velimir Khlebnikov i ukrainskaya mifologiya. [Velimir Khlebnikov and Ukrainian mythology]. dis. ... kand. filol. nauk: AN Ukrainy, In-t lit. im. T. G. Shevchenko. Kiyev, 1993. [in Russian].

8. Kravets V. Razgovor o Khlebnikove. [Conversation about Khlebnikov]. Kiyev: RVTS "Proza", 1998.288 p. [in Russian].

9. Livshits B. Polutoraglazyy strelets: Stikhotvoreniya, perevody, vospominaniya. [Half-Eyed Sagittarius: Poems, Translations, Memories]. Leningrad: Sovetskiy pisatel', 1989. 720 p. [in Russian].

10. Movchan R. Khlyebnykov i ukrayins'kyy futuryzm. [Khlebnikov and Ukrainian futurism]. Bakhmut·s'kyy shlyakh. 2010. № 1-2, P. 131-136. [in Ukrainian].

11. Pasternak B. Stikhotvoreniya i poemy. [Verses and Poems]. Leningrad: Sovetskiy pisatel', 1990. V. 1. 504 p. [in Russian].

12. Petrovskiy M. Svyatoshinskiye vakatsii Velimira Khlebnikova. [Svyatoshinsky vacations by Velimir Khlebnikov]. Petrovskiy M. Gorodu i miru. Kiyevskiye ocherki. Kiyev: Radyans'kiy pis’mennik, 1990. P. 93-97. [in Russian].

13. Sedakova O. Etnograficheskiy kommentariy k odnoy strofe Khlebnikova. [Ethnographic commentary on the one stanza by Khlebnikov]. Poeziya i zhivopis': Sb. trudov pamyati N. I. Khardzhiyeva. Moskva: Yazyki russkoy kul'tury, 2000. P. 352-356. [in Russian].

14. Stepanov N. Velimir Khlebnikov. Zhizn' i tvorchestvo. [Velimir Khlebnikov. Life and creative work]. Moskva: Sovetskiy pisatel', 1975. 281 p. [in Russian].

15. Spesivtseva L. Zhanrovoye svoyeobraziye poemy V. Khlebnikova «Siniye okovy". [Genre originality of V. Khlebnikov’s poem "Blue shackles”]. Vestnik Astrakhanskogo gos. un-ta. 2005. № 6 (29), P. 281-292. URL: https://cyberleninka. $\mathrm{ru} /$ article/n/zhanrovoe-svoeobrazie-poemy-v-hlebnikova-sinie-okovy/viewer (Accessed: 12.07.2020). [in Russian].

16. Khlebnikov V. Tvoreniya. [Creations]. Moskva: Sovetskiy pisatel', 1986. 736 p. [in Russian].

17. Khlebnikov V. Polnoye sobraniye sochineniy. V. 1 Stikhotvoreniya 1904-1916. [Full composition of writings. Vol. 1 Poems 1904-1916]. Moskva: IMLI RAN, Naslediye, 2000. URL: https://ruslit.traumlibrary.net/book/hlebnikov-ss06-01/hlebnikov-ss06-01.html (Accessed: 04.11.2020). [in Russian].

18. Khlebnikov V. Polnoye sobraniye sochineniy. V. 3. Poemy 1905-1922. [Full composition of writings. T. 3. Poems 1905-1922]. Moskva: IMLI RAN, 2002. URL: https://ruslit.traumlibrary.net/book/hlebnikov-ss06-03/hlebnikov-ss06-03. html (Accessed: 04.11.2020). [in Russian].

19. Chizhevskiy D. O poezii russkogo futurizma. [On the poetry of Russian futurism]. The New Review. Novyy zhurnal. Nyu-York, 1963. Kn. 73. P. 132-169. [in Russian].

20. Chyzhevs'kyy D. Ukrayins'ke literaturne baroko. [Ukrainian literary baroque]. Kyyiv: Oberehy, 2003. 576 p. [in Ukrainian].

21. Yakobson R. Noveyshaya russkaya poeziya. Nabrosok pervyy: Podstupy k Khlebnikovu. [The latest Russian poetry. Sketch one: Approaches to Khlebnikov]. Praga, 1921. URL: http://philologos.narod.ru/classics/jakobson-nrp.htm (Accessed: 12.07.2020). [in Russian].

22. Markov V. Russian Futurism: A History. Berkeley and Los Angeles: Univ. of California Press, 1968. 467 p. [in English]. 